\title{
Comments
}

\section{CONTROL OF URBAN SPRAWL OR SECURING OPEN SPACE: REGULATION BY CONDEMNATION OR BY ORDINANCE?}

The modern phenomenon of metropolitan expansion, which is steadily replacing the natural flora of the countryside with a loorticulture of tract housing, has generated a great deal of concern about the conservation of open space. The leading prophet of the forthcoming plague of metropolitan sprawl, Wilkam $\mathrm{H}$. Whyte, Jr., has sounded a cry to action calling for the immediate public acquisition of developmental rights in all remaining strategically located "open spaces." $1 \mathrm{He}$ prefers the acquisition of "conservation easements" to the traditional techniques available under the police power for two reasons, one apparently ideological and the other practical. The purpose of this comment is to evaluate the legality and utility of this tool as opposed to an expanded use of the police powers. Its main thesis is that the desire to conserve open space is motivated by a desire to create a well balanced environment which will not suffocate its creator; that althougl the acquisition of developmental riglits, with adequate safeguards, is probably legal, its utility as an instrument of regulation and channeling future growth is extremely limited.

\section{PURPOSES AND OBJECTIVES}

Preliminarily, it is necessary to determine what the objectives of an open space program are, for the validity of the means will depend, in part, upon low these objectives are characterized. Whyte asserts that "open space must be established as a benefit in its own right and a benefit now." In his view the objectives are primarily aesthetic and the goals immediate. This approach has been criticized on the ground that open space is not beneficial by itself but is "socially useful or desirable only as it relates to other environmental conditions."3 The objection seems sound. As our cities continue to grow and expand, a variety of interrelated values should be considered in formulating the purposes and policies of an open space program. Regulation may be desirable to prevent development in physically unsuitable or uneconomic locations; to prevent congestion and create collesive communities; to preserve and protect agriculture as a necessary and desirable part of a well balanced community; to provide for recreation areas; and to preserve elements of beauty and spaciousness in our environment.. The problem is not so mucl that the open countryside is being invaded by the bulldozer, which is an unavoidable consequence of the modern population and metropolitan explosion, but that the expansion is proceeding according to the dictates of the market place without adequate consideration being given to the long range

1 Whyte, Securnng Open Space for Urban Amireica: Conservation Easeacents (Urban Land Institute Technical Bull. No. 36, 1959) [hereinafter cited as WEXTE].

2 Id. at 18.

8 Davidoff, Book Review, 26 J. American Institute of Pianners 337, 339 (1960).

4 For further discussion see Krasnowiecki \& Paul, The Preservation of Open Space in Metropolitan Areas, 110 U. PA. L. REv. 179, 180-84 (1961). 
requirements of the community. "Failure to separate questions dealing with open space as an end from those dealing with it as a means can only serve to confuse and mislead the public, decision-makers, courts, and planners. Open space is one social objective among many; it should not be given primacy unquestioningly." The difference in emphasis has important legal and planning consequences. As a planning concept open space must be defined by the design criteria that will contain it and form its boundaries. Absent economic and utilitarian considerations, the planner is left with hittle or no objective standard or discipline. Legislation without such standards may raise serious constitutional problems. The ultimate determination and formulation of the objectives of an open space program rests with the legislature. In light of the above differences the following discussion attempts to evaluate the developmental rights approach by considering both approaches to the problem.

\section{II}

\section{VALIDITY OF THE MEANS}

\section{General}

\section{A. Developmental Rights}

The ultimate effect of the developmental rights approach is the imposition of restrictions on the use of land by condemnation. It envisions the public acquisition of an interest in the nature of a negative easelnent preventing development while ownership in the fee renrains undisturbed. Although the interest may be acquired by voluntary agreement, an effective open space program will require authorization to condemn. The threshold question, therefore, is whether it is within the power of the legislature to authorize the exercise of the power of eminent domain to accomplish the purposes of an open space program.

\section{Objectives Utilitarian as Well as Aesthetic}

Assuming the objectives are utilitarian as well as aesthetic and are reflected in a comprehensive plan, recent decisions indicate that the acquisition of developnental rights will be upheld.

In Berman v. Parker ${ }^{6}$ the United States Supreme Court upheld the vahdity of a redevelopment act authorizing the acquisition and sale of real property for the redevelopment of blighted territory and the prevention of blighting factors. The authorization was pursuant to a legislative finding that conditions of blight existed that could not be eliminated by the ordinary operations of private enterprise or without comprehensive and coordinated planning. The district court had held the act constitutional by narrowly construing it to authorize condemnation only for slum clearance. ${ }^{7}$ That court felt that absent public use or "compelling public necessity," the individual's rights were superior to the government's and that the mere creation of a pleasant neighborhood was not a valid public purpose justifying the exercise of the power of eminent domain. ${ }^{8}$ In modifying this judgment, the Supreme Court characterized the act as an exercise of the police power,

5 Davidoff, supra note 3 , at 339 .

6348 U.S. 26 (1954).

7 Schneider v. District of Columbia, 117 F. Supp. 705 (D.D.C. 1953).

8 Id. at 724. 
stating that such power was not limited to the maintenance of public lealth and safety but also included the power "to determine that the community should be beautiful as well as healthy, spacious as well as clean, well balanced as well as carefully patrolled;" that "once the object is within the authority of Congress the riglit to realize it through the exercise of eminent domain is clear."10 The Court concluded that, once the public purpose was established, the means of executing a project and the amount and character of the land to be taken for the project was for the legislature alone to determine.

The California courts have followed the federal analysis fairly closely. In Fellom v. Redevelopment Agency ${ }^{11}$ the court upheld the constitutionality of the California redevelopment law as applied to non-slum type bliglited areas or to undeveloped vacant land areas. In so holding the court limited an earlier decision ${ }^{12}$ which had held the same act constitutional by adopting and applying the "compelling community economic need test" of the district court's opinion in Berman. The court noted that this opinion had been superseded by that of the Supreme Court and limited its prior decision to holding the act constitutional as applied. Significantly the court quoted Berman to the effect that the courts would not reappraise legislative determinations of purpose or necessity and that the riglits of the property owners were satisfied once they were compensated. In light of the broad language of Berman and Fellom it would seem fairly certain that legis: lation authorizing the acquisition of developmental rights in open space to control urban growth and to conserve the aesthetic and economic resources of a community will be upheld.

The power to condemn private property for a valid public purpose is not, however, unlimited. It has been sustained only where the power was exercised pursuant to a comprehensive plan and was designed to eliminate "blight" that prevented private developinent. The significance of these two factors is not to be underestimated. They may represent additional and perhaps dependent constitutional limitations. In City and County of San Francisco v. Ross ${ }^{13}$ it was held that the power of eminent domain could not be exercised to acquire possession of land to be leased to a private individual for the construction and maintenance of off-street parking facilities because no "controls" were provided to assure that the property condemned would be used in the public interest. The court distingnished Berman on the ground that lessees or purchasers from the governneent were there required to use the land in conforinance with a comprehensive and general plan designed to assure redevelopment in a manner to protect the public health, safety and welfare. Thus, it would appear that condemnation of private property for a purpose otherwise valid but without adequate controls such as a compreliensive plan, may be struck down, particularly where transfer of ownership is contemplated.

Although the initial acquisition of developmental riglts in open space areas may be designed primarily to prevent development and not to foster development by transferring ownership, $\mathrm{m}$ order for it to be an effective instrument of govern-

${ }^{9}$ Berman v. Parker, 348 U.S. 26, 33 (1954).

10 Ibid.

11 157 Cal. App. 2d 243, 320 P.2d 884 (1958).

13 Redevelopment Agency v. Hayes, 122 Cal. App. 2d 777, 266 P.2d 105 (1954).

1344 Cal. 2d 52, 279 P.2d 529 (1955). 
ment policy it must comprehend growth and change. As the population expands and the loousing needs of an area grow it will undoubtedly become necessary to permit or even require development of open space areas. Just how this programming is to be accomplished is not clear. It may require the power to condemn non-bhighted territory for resale to permit development. An uncompensated release of the developmental rights to the owner of the fee could be attacked as an invalid gift of public funds. ${ }^{14}$ Resale to the owner of the fee would be possible if he were a ready and willing buyer, but a forced purchase would hardly seem possible. If the right to enforce the restrictions were assignable, which would seem questionable,,$^{15}$ it could be sold to a third party who would still have to purchase the fee, and probably at an inflated value. In effect, the initial acquisition of developmental rights may have created a condition of "planning blight" which would necessitate the condemnation and sale of the fee in order to make development feasible. The result of the combined condemnations would be the transfer of non-slum, nonblighted property of one person to another, solely to program the development of an area probably at a considerable savings or profit to the government. Althougl Berman upheld the power to condemn innocuous and unoffending property for resale, the transfer was occasioned by external conditions of blight which prevented private development, not by conditions caused by the government itself.

The power of eminent domain may be exercised to put slum or "blighted" areas into productive use by condemnation and resale or to prevent development of non-slum, non-blight open areas. Nevertheless, the ultimate question remaining is whether or not this power can be used to program development of unoffending property by successive condemnations and resale for private use. The premature and unnecessary condemnation of non-blighted private property for possible transfer to another or for some future public use has been found objectionable by at least one court despite Berman. ${ }^{10}$ An open space program including the power to condemn the fee or any lesser interest and the power of resale may well be at the outer limits of constitutionality, particularly where the transactions are not controlled by a comprehensive plan.

\section{Aesthetic Objectives Only}

The constitutionality of $a d$ hoc acquisition of developmental rights removed from the context of controlled development, without a comprehensive plan, without any public use, justified solely for aesthetic purposes, is highly questionable. Conceivably, under the language of Berman, aesthetic considerations alone without any accompanying utilitarian objective may justify the exercise of eminent domain powers. No case has so held. ${ }^{17}$

Even if aesthetic objectives are by themselves valid, a public purpose of established validity may not justify the exercise of the power of eminent domain

14 Mallon v. City of Long Beach, 44 Cal. 2d 199, 282 P.2d 481 (1955); Car. Const. art. IV, § 31 .

15 Although the requirement that persons seeking enforcement of an interest affecting land hold the land intended to be benefited may not be applicable to a government authority representing all property owners, query whether it would be waived so as to permit assignment of the interest. See Krasnowiecki \& Paul, supra note 4, at 194 n.57.

16 In re Opinion of the Justices, 332 Mass. 769, 126 N.E.2d 795 (1955).

17 See Bergs, Aesthetics as a Jistification for the Exercise of the Police Power or Eminent Domain, 23 Geo. Wash. L. Rev. 730 (1955); Comment, 12 Stan. L. Rev. 638, 648 (1960). 
in the absence of some guaranty that the interest is being acquired to further that purpose. A variety of analogous easements, such as highway and park scenic easements, have been cited to establish the validity of the so-called "conservation easement."18 In these cases, however, open space is being acquired to preserve or protect an independently justifiable objective such as park, highway or airport construction. The exercise of the power is controlled to a large degree by the physical limitations of the particular project. The ad hoc acquisition of a negative easement does not carry with it any such inherent restraint or objective limitation. The exercise of the power may be as boundless as open space itself. The necessary control, if it can be obtained at all, must be found either in the restrictions themselves or in some procedural safeguard. Inflexible restrictions may prevent adjustunent to changing conditions ${ }^{19}$ resulting in undue hardship to the owner and requiring subsequent condemnation to eliminate planning blight. Vague and flexible restrictions, removed from the context of a comprehensive plan, may raise the specter of Ross on the one hand and problems of compensation and enforcement on the other. ${ }^{20}$

\section{Compensable Property Interest}

Assuming that the acquisition of developmental riglits is a valid means, the problem of defining what is being acquired remains. This presents a close parallel to the foregoing constitutional analysis. Presumably, the use of the land will be restricted so as to preserve the existing use and to prevent new building, roadway or billboard construction, or greenery removal. On the other hand, in order to achieve some degree of flexibility, a change in use may be permitted if it conforms with the purposes of the easement. Similarly, the restriction may be terminated altogether if the purposes are abandoned.21 The restrictions are not like the traditional easements that permit actual plysical use of the land, nor are they like a covenant that runs with the land. Both of these carry with them their own self-discipline or control. The restrictions on developmental rights appear to be more like a restrictive covenant or equitable servitude for the benefit of the landowners in a particular area ${ }^{22}$ which are only enforceable if made according to a general scheme involving uniform restrictions. ${ }^{23}$ The riglit to condemn a similar interest lias been demed altogetler on the ground that the restrictions sought to be imposed were too indefinite. ${ }^{24}$ Similarly, the owner of land benefited by a restrictive covenant has been denied compensation for the condemnation of the servient land on the ground that the interest is no more than a negative easement which is not a property right entitled to compensation. ${ }^{25}$

18 SIEgex, THE LAW OF OPEN SPACE 29-32 (1960); WHXTE 11-15.

10 For a discussion of the English treatment of changing conditions and the still unresolved problems involved, see Mandelker, Notes from the English: Compensation In Town and Country Planning, 49 CaIrF. L. Rev. 699 (1961).

20 For further discussion, see Krasnowiecki \& Paul, supra note 4, at 192-94.

21 WHYTE 44.

22 Burger v. City of St. Paul, 241 Minn. 285, 64 N.W.2d 73 (1954); see Krasnowiecki \& Paul, supra note 4, at 192.

23 See, e.g., Werner v. Graham, 181 Cal. 174, 183 Pac. 945 (1919) ; Robertson v. Nichols, 92 Cal. App. 2d 201, 206 P.2d 898 (1949).

24 Pontiac Inprovement Co. v. Board of Comm'rs, 104 Ohio St. 447, 135 N.E. 635 (1922).

25 Friesen v. City of Glendale, 209 Cal. 524, 288 Pac. 1080 (1930). But see Burger v. City of St. Paul, supra note 22. 
Even if a skilled draftsman can achieve the delicate balance between permanency and controlled flexibility to assure recognition of the interest as a property right, the problems of definition find their counterpart in problems of compensation.

Where development is imminent, a fairly accurate appraisal of the developmental value may be achieved. Where, however, development is remote and there is little or no present developmental value it must nevertheless be considered. ${ }^{26}$ This may well lead to inflated awards based on conjecture and speculation.

The more difficult evaluation problem is presented by the possibility that the restriction may be terminated at some time in the future. Where the fee is condemned and there is a reasonable probability that a zoning ordinance or similar restriction will be changed in the near future, the effect of such change may be taken into consideration in determining the fair market value of the land. ${ }^{27}$ By a parity of reason, where it is the restriction itself which is to be evaluated, a reasonable probability of a change in the near future may also be taken into consideration. As pointed out above, as the housing or developmental needs of an area increase, it may become desirable to release the restrictions on development. To avoid the objection that an uncompensated release would be a gift of public funds, the possibility of the release should be considered in the initial evaluation. Unless the value of the probability of release represents the present value of the increment in developmental value which would accrue to the owner when the restrictions are terminated, a gift of public funds may occur.

Thus it would seem that the interest acquired under an open space program is peculiarly susceptible to speculation and conjecture. What superficially appears to be a just procedure may in practice turn out to be inherently inequitable both to the landowner and the public.

\section{B. Police Power}

\section{General}

Assuming the legality of the developmental rights approach, an evaluation of the utility of that means requires a comparative study with other means available. It is therefore necessary to determine to what extent the Constitution requires compensation for the necessary restrictions and to what extent it permits non-compensable regulation under the police power.

The line between a valid non-compensable regulation and an invald "taking" without compensation is not easily drawn. It is not enough to justify a regulation under the police power to say that it is in the public interest. Nor does the mere restriction of property rights require compensation. These elements are necessary incidents of both condemnation and police power regulation. It does not solve the problem to say that the exercise of the police power is limited to the prevention of liarm and that the public must pay for the detriment caused by mere beneficial regulation. ${ }^{28}$ Theoretically, all restrictions are designed to confer benefits by pre-

${ }^{28}$ City of Los Angeles v. Hughes, 202 Cal. 731, 262 Pac. 737 (1927); Santa Clara County Flood Control v, Freitas, 177 Cal. App. 2d 264, 2 Cal. Rptr. 129 (1960).

27 Long Beach City High School Dist. v. Stewart, 30 Cal. 2d 763, 185 P.2d 585 (1947).

28 Contra, Dunham, $A$ Legal and Economic Basis for City Planning, 58 Colum. L. REv. 650, 663-69 (1958); WHYTE 25-29. 
venting conduct which is deemed harmful in some way. ${ }^{29}$ Rather, the constitutionality of a regulation as a valid exercise of the police power turns on whether or not, in each case, the restriction or burden is reasonable in light of the circumstances and benefits sought to be achieved. ${ }^{30}$

With an open space program, this determination will depend in part on how the objectives are characterized. If they are primarily aesthetic, Whyte's contention that this is a public benefit for which the public will have to pay is probably valid. Although regulations to preserve aesthetic values that have a pecuhar economic value to the community have been upheld, regulation for aesthetic purposes without any economic or utilitarian objective may well impose an insufficiently justifiable burden on the individual landowner. ${ }^{31}$ As discussed earlier, even condemnation for such a restricted purpose is not without its constitutional difficulties.

Quite a different problem is presented where the objectives are not so limited but are expanded to include the more comprehensive goals discussed earher, i.e., the control of urban growth to obtain the most efficient and desirabie utilization of our economic and aesthetic resources. The cases indicate ${ }^{32}$ that such objectives are clearly within the police power; therefore, the problem becomes one of determining whether a regulation designed to accomplish these objectives is reasonable. A regulation indefinitely preventing any reasonably beneficial use of the land ${ }^{33}$ or restricting development to reduce the cost of future acquisition would be clearly invalid..$^{34}$ On the other hand, development may be proscribed where it might reasonably be found that the land is unsuitable for development and no showing is made that the land cannot be used for other purposes. ${ }^{35}$ The problem reduces itself to determining whether or not development may be proscribed where the land is clearly suitable for development but is also useable for other purposes such as agriculture or recreation. It is this land that probably constitutes the bulk of the open space remaining in metropolitan regions, where future growth and pressure are to be felt and directed. It must, therefore, form the focal point of any legal evaluation. In this framework two different legal problems are presented; the first relates to restrictions on agricultural land, and the second relates to restrictions on private recreational land such as golf clubs, country clubs, and beach areas.

\section{Agricultural Zoning}

It would seem that the basic objections to agricultural zoning are first, that it would cause property to be unimproved for an unpredictable or unforeseeable length of time, and second, that it would be unconstitutional to prevent "higher"

29 Furthermore, this position is clearly not the law in California. In the landmark case of Miller v. Board of Pub. Works, 195 Cal. 477, 487-88, 234 Pac. 381, 384 (1925), the court stated that "the police power as evidenced in zoning has a much wider scope than the mere suppression of the offensive use of property .... it acts not only negatively but constructively and affirmatively for the promotion of the public welfare."

30 Pennsylvania Coal Co. v. Mahon, 260 U.S. 393 (1922); Hunter v. Adams, 180 Cal. App. 2d 511, 522, 4 Cal. Rptr. 776, 783 (1960); Galt v. Cook County, 405 IIl. 396, 91 N.E.2d 395 (1950).

31 See Bergs, Aesthetics as a Justification for the Exercise of the Police Power of Eninent Domain, 23 GEo. Wase. L. REv. 730 (1955).

32 Berman v. Parker, 348 U.S. 26 (1954).

33 Averne Bay Constr. Co. v. Thatcher, 278 N.Y. 222, 15 N.E.2d 587 (1938).

34 Miller v. City of Beaver Falls, $368 \mathrm{~Pa}$. 189, 82 A.2d 34 (1951). But see Hunter v. Adams, 180 Cal. App. 2d 511, 4 Cal. Rptr. 776 (1960).

85 McCarthy v. City of Manhattan Beach, 41 Cal. 2d 879, 264 P.2d 932 (1953). 
residential uses from invading "lower" agricultural ones. Neither position is tenable. Under the former, the question is not whether the land may be improved, but whether or not it is useable as zoned. The second objection was expressly rejected in Roney v. Board of Supervisors, ${ }^{36}$ where exclusive industrial zoning was upheld, partly on the ground of protecting residents, but primarily on the ground that secondary or "lower" uses may also be protected. In light of the necessary and vital role of agriculture in our society, the incompatibility of agricultural with other uses, the imflated service costs and reduced aesthetic value of unplanned development, the deference given legislative judgment, and the modern expansion of the police power to meet contemporary conditions of life, it would seem fairly certain that regulations restricting land to agricultural use as part of a comprehensive plan of sound urban development will be upheld. No cases have been found holding agricultural zoning per se constitutional. Recent decisions in California upholding such regulations as applied, however, suggest their ultimate validity. In Mang $v$. County of Santa Barbara ${ }^{37}$ the contention was made that the county policy of zoning very large areas for agricultural use only and requiring individual landowners to apply for exceptions was contrary to the statutory requirements of long-term comprehensive planning. This contention was rejected, the court stating that "nothing in the Government Code disempowered the .. . county from attempting to meet the various serious problems arising as a result of population influx. The determination ... that areas of grazing and farm land should be zoned for agricultural purposes is a matter clearly within the competence and province of the board of supervisors." 38

Similarly, in Paramount Rock Co. v. County of San Diego, ${ }^{30}$ the court held that the addition of a rock crushing plant to a concrete pre-mixing plant was an unlawful expansion of a permitted non-conforming use in violation of an agricultural zoning ordinance. In order to reach the above issue the court concluded that "the evidence [that land similarly situated in the river bed had been used for golf courses, dairy farms, riding stables, cattle grazing, etc.] substantially supports the implied finding of the trial court that it was not unreasonable to categorize the area within an agricultural zone." 40

A recent decision ${ }^{41}$ of the California Supresne Court upholding an ordinance that prohibited the operation of a rock crushing plant and in effect restricting the land to agricultural uses of relatively minimal value lends added weight to this conclusion. Here the trial court had found that the restricted land had no appreciable economic value as zoned and that the prohibited use could be conducted with "compatibility to adjacent properties and with minimal detriment to the living amenities of health conditions . . . of adjacent properties ... and without probable depreciation in property values . . ."42 The trial court also found that the rock and gravel operation could have a deleterious effect on the area's reputation as a haven for sufferers from respiratory ailments, thus injuring its economy. The trial court concluded that reasonable minds might differ on these matters and that in

36 138 Cal. App. 2d 740, 292 P.2d 529 (1956).

37182 Cal. App. 2d 93, 5 Cal. Rptr. 724 (1960).

$38 \mathrm{Id}$. at $101,5 \mathrm{Cal}$. Rptr. at 730 .

39180 Cal. App. 2d 217, 4 Cal. Rptr. 317 (1960).

40 Id. at 225, 4 Cal. Rptr. at 322.

41 Consolidated Rock Prods. Co. v. City of Los Angeles, 57 A.C. 557,20 Cal. Rptr. 638 (1962).

42 Id. at 561, 20 Cal. Rptr. at 640. 
such a case it was not for the courts to interfere with the legislative determination. The supreme court affinned, stating that there was evidence that "the property could be successfully devoted to certain other uses, i.e., stabling horses, cattle feeding and grazing, chicken raising, dog kennels, fish hatcheries, golf courses, certain types of horticulture and recreation." 43 The court concluded that even if such uses were of relatively minimal value, once there is evidence upon which reasonable minds unight differ the courts should find in favor of the ordinances constitutionality. Legislative determinations of the necessity and propriety of agricultural zoning to protect the agricultural industry itself as well as the reputation and economy of the area should clearly be valid.

\section{Recreational Zoning}

Regulations restrictimg development in open recreational areas such as golf courses and beaches present quite a different problem. If the public may only enjoy the view, the benefit is primarily aesthetic and the regulation may be constitutionally objectionable on that ground. If the public may also enjoy the facilities, the benefit may nevertheless be insufficient to justify the burden. Recreation is a considerably less critical factor than agriculture in our society. Standing alone it may not carry the balance in favor of reasonableness and ultimate vahdity. Although a recreational beach zoming ordinance has been upheld, the decision was primarily based on a finding that the land was unsuitable for residential use. ${ }^{44}$

In addition to land use regulation, several other methods of regulation are available under the police power to accomplish the desired end. Large lot zoning has been held constitutional in certain instances, but its utility as a tool is highly limited. ${ }^{45}$ Although the Subdivision Map Act is limited to the regulation of desigu and improvements, the master plan and zoning ordinances of a county are of equal dignity and may exclude a subdivision entirely. ${ }^{46}$ The availability and utility of this kind of control is largely unexplored and needs further evaluation.

\section{Spot Zoning}

One further limitation on the use of the police power to accomplish the purposes of an open space program must be noted. Even though a regulation permits a beneficial use which is in the public interest in the traditional sense it may nevertheless be unreasonable, arbitrary, or discriminatory in that it treats a particular land owner or area differently from others similarly situated in a given area. ${ }^{47}$ Although the constitutional requirement of equal protection of the laws is apphcable to individuals and not areas, ${ }^{48}$ it finds its counterpart in the constitutional prohibition against "spot zoning." The precise nature of this prohibition is not clearly defined but it is fairly certain that the reasonableness of land use classifica-

43 Id. at 572, 20 Cal. Rptr. at 647.

44 McCarthy v. City of Manhattan Beach, 41 Cal. 2d 879, 264 P.2d 932 (1953).

45 Steger, The Law of Open Space 39 (1960).

46 Roney v. Board of Supervisors, 138 Cal. App. 2d 740, 292 P.2d 529 (1956); CaL. Bus. \& Prof. Code $\S \S 11500-640$.

47 Galt v. Cook County, 405 IIl. 396, 91 N.E.2d 395 (1950) (holding invalid a zoning ordinance restricting vacant land surrounded by commercial and industrial uses to residential use); Vernon Park Realty Inc. v. City of Mount Vernon, 307 N.Y. 493, 121 N.E.2d 517 (1954).

48 Brooks, The Metropolis, Home Rule, and the Special District, 11 Hastivgs L.J. 110, 246,262 n.154 (1959). 
tion will depend in part on the nature of the permitted and existing uses in the surrounding area. It does not suffice to say that all those within a particular area are treated similarly, for the uses on both sides of the boundary inust be considered in order to determine whether the restriction is reasonable. It may be unreasonable because the surrounding uses inake the restricted use undesirable or impracticable..$^{99}$ It may also be unreasonable because it places a special and peculiar burden on a selected landowner or area totally unrelated to any special benefit received or to any offensive use of the particular property, ${ }^{50}$ in effect being a special assessinent for the general benefit of the community.

In relation to an open space program, agricultural zoning which is valid in rural areas may be invalid when the immediately surrounding territory is heavily developed. Recreational or aesthetic zoning otherwise valid may be peculiarly susceptible to attack as spot zoning for such areas are often surrounded by development. Similarly, dedication or reservation of open space areas as a condition precedent to subdivision approval may be valid where it is designed to fulfill needs attributable to the particular subdivision, but invalid if imposed for the general benefit. ${ }^{61}$

\section{III}

THE UTILITY OF THE MIEANS

\section{A. General}

If the above analysis is correct and the bulk of the existing open space areas are amenable to regulation both by condemnation and by ordinance, the legal problem reduces itself to the practical one of deciding which of the two means available will best accomplish the objectives of the program. Again, two types of interrelated problems are presented: those relating to taxation and finance and those relating to control and flexibility.

\section{B. Finance and Tascation}

\section{Developmental Rights}

Finance. The most obvious and immediate problem confronting the developmental rights approach is that of finance. Any significant program to acquire these rights will require a large initial expenditure of public funds. Although the Federal Housing Act of 1961 authorizes expenditures to help finance acquisition of title or other permanent interest in open space land located in urban areas, the purposes for which the grants are available seem to be limited to recreation, conservation, and the preservation of scenic and historic areas. ${ }^{52}$ In the absence of federal or state assistance, the funds will have to come from local resources and will no doubt require financing. Any indebtedness or liability incurred by a city or county in any year that exceeds the income or revenue for that year is subject to the constitutional debt limitation requiring approval of two-thirds of the voters. ${ }^{53}$ This is true

49 Galt v. Cook County, 405 III. 396, 91 N.E.2d 395 (1950).

50 Vernon Park Realty Inc. v. City of Mount Vernon, 307 N.Y. 493, 121 N.E.2d 517 (1950).

51 Ayres v. City Council, 34 Cal. 2d 31, 207 P.2d 1 (1949).

62 Housing Act of 1961, §§ 701-06, 75 Stat. 183 (1961), 42 U.S.C. $\S 1500$ (b) (Supp. III, 1962). See Krasnowiecki \& Paul, supra note 4, at 213.

${ }^{63}$ City of Oxnard v. Dale, 45 Cal. 2d 729, 290 P.2d 859 (1955); Car. Const. art. XI, 818. 
even where the obligation is to be paid in installments. ${ }^{54}$ This limitation appears to place a large obstacle in the path of the developmental riglits approach. Although the urgency of the need may be apparent to those particularly concerned with the problem, until it is commumicated to the public with sufficient force to win a twothirds majority at the polls, the funds will not be forthcoming from the general revenues.

Conceivably, the constitutional debt limitation could be avoided by financing the program from the special funds acquired from the purcliase and sale of open space land. ${ }^{55}$ Such a program would, however, raise serious constitutional problems and may be politically distasteful as well. The impasse may also be avoided by placing the administration of the program in the hands of an agency, other than a city or county, that would not be subject to the debt limitation. ${ }^{56}$

Taxation. The financial limitations on the developmental rights approach are reflected in matters of taxation. If the acquisition of these riglits is not financed by special funds or through some regional agency, the tax saving that is supposed to inhere to the benefit of the restricted landowners by reason of reduced evaluations for assessment purposes ${ }^{57}$ may be illusory. Where the taxing and condemning jurisdiction is coextensive with the open space areas to be preserved, the cost and tax burden of the acquisition of the developmental rights will probably fall primarily on the landowners whose rights are being condemned. In effect, they would be paying for their own self-regulation and taxing themselves to reduce taxation. Unless the increased tax burden, the reduced assessment, and the price paid for the developmental value somelow balance out, the results may be mequitable.

The supposed tax savings of the developmental rights approach appear to be illusory for another reason. The restrictions imposed on the land are supposed to reduce taxes by requiring evaluation as restricted. If, however, the reasonable probability of a release of the restriction in the near future may be considered in evaluating the land for condemnation purposes it may also be considered for taxation purposes. Unless a greater degree of permanency is somelow created by condemnation, the developmental rights approach may find itself on the same footing as the police power in this regard. The possibility of the release of the restriction may result in inclusion of the developinental value in evaluation for tax purposes. ${ }^{58}$

\section{Police Power}

Finance. Regulation of land use under the police power is not burdened with the same financial limitations. It has been suggested, lowever, that a general scheme of regulation that prevents developinent except where the owner can show that his land cannot yield a reasonable return as restricted would result either $\mathrm{m}$ patch-work disruption or "condemnation at values inflated by the unspoiled charsrter of the surrounding properties." 59 The latter result does not necessarily follow.

54 Whyte has suggested installment payments as a possible ineans of avoiding the high initial cost of his prograin. WHXTE 48. Nevertheless, unless each year's installments are within the city's income and each year's payment is for the consideration actually furnished that year the debt is still subject to approval of two-thirds of the voters. Garrett v. Swanton, 216 Cal. 220, 13 P.2d 725 (1932).

55 Cf. City of Oxnard v. Dale, 45 Cal. 2d 729, 290 P.2d 859 (1955).

vo CAI. Const. art. XI, $\S 18$.

57 WHYTE 38-41.

68 Id. at 39. See also Cax. Rev. \& TAX. CODE $\S 402.5$.

59 Krasnowiecki \& Paul, supra note 4, at 187. 
The benefit attributable to condemnation pursuant to a comprehensive plan of development need not be considered in determining fair market value for compensation purposes ${ }^{60}$ Condemnation to prevent disruption of such a plan may be similarly treated by the courts, thereby reserving to the government the benefits of its own conduct.

Taxation. Regulations under the police power have also been attacked on the ground that they do not prevent inclusion of the developmental value of land in evaluation for tax purposes. As previously discussed, however, the same criticism may be applicable to the developmental rights approach.

Clearly what is needed under either approach is a tax structure that will abate rather than accelerate the spiral effect of development, i.e., development demanding new services, increasing tax burden, increasing assessment, and forcing sale for development demanding further new services. The solution is a tax structure that places the burden of providing new services on those who are peculiarly benefited. Conceivably, this could be accomplished by taxing at the restricted value but requiring, as a condition precedent to the issuance of a building permit, the payment of the taxes that would have been paid had the land been taxed at its unrestricted value. ${ }^{61}$ If the back tax assessment is reasonably related to the increased cost of services attributable to the particular development a fairly equitable solution may result. If not so related, the development would at least be sliaring the cost of services that it has precipitated. An attempt to arrive at a similar solution was held invalid when the device used was payment of a subdivision fee as a condition precedent to subdivision approval. ${ }^{62}$ It may be more successful when presented as an attempt to collect back taxes.

\section{Control and Flexibility}

\section{Control}

In addition to the ideological criticism levelled against any major reliance on the police power to accomplish the ultimate purposes of an open space program the objection has been made that these inethods have been too easily affected by market and political pressures. ${ }^{63}$ It would seem, however, that this "irresponsibility" is largely due to a lack of coordination and control on a regional basis. In the absence of a regional agency to control development and inetropolitan expansion, local pohtical expediency necessarily will govern county and city planning decisions. Market pressures on landowners in open areas, reflected in political pressures on governing authorities responsible solely to local interest, may well result in piecemeal and impermanent planning. Furthermore, the power to regulate is restricted to the respective jurisdictions of the city or county. City ordinances supersede county ordinances within the city but have no effect outside its boundaries. ${ }^{64}$

60 United States v. Miller, 317 U.S. 369 (1942).

61 For discussion of relation of taxing devices to open space program see SIEGEL, THE LAW of Open Space 43-49 (1960); Whyte 38-41.

62 Kelber v. City of Upland, 155 Cal. App. 2d 631, 318 P.2d 561 (1957). The imperfection may be cured if a reasonable relationship between the subdivision fee and increased cost of services is demonstrated, thus eliminating the objection that the exaction is a special assessment for the general benefit. See Longridge Estates v. City of Los Angeles, $183 \mathrm{Cal}$. App. 2d 533, 6 Cal. Rptr. 900 (1960) ; CaI. Bus. \& Prop. Code $\$ 11543.5$.

63 Siegei, The Law of Open Space 37-41 (1960); Wryte 24.

64 Ex Parte Roach, 104 Cal. 272, 37 Pac. 1044 (1894). 
Although there is no constitutional limitation on the extraterritorial application of the power of eminent domain, ${ }^{65}$ the developmental rights approach would seem to be equally susceptible to market and pohtical pressures. There is no inherent safeguard in the restrictions imposed by the developmental rights approach which would make them less subject to this kind of pressure. In fact, insofar as this impermanency is due to a lack of planning and procedural safeguards against arbitrary and discriminatory conduct on the part of local agencies, regulation by condemnation seems inherently more dangerous.

It lias been stated that the very essence of a valid zoming scheme is a comprehensive plan of development or land use. ${ }^{66}$ With few exceptions, police power regulations are general in application and do not single out selected individuals for special treatment. No such statement may be made about condemnation, which, on the contrary, is generally conducted on an individual basis without any overall scheme. Whyte himself suggests that it would be a poor planner indeed who could not think of some land to run out and buy before it all disappeared. ${ }^{67}$ Furthermore, property owners affected by a zoning ordinance are entitled to public notice and liearing; 68 amendments to a zoning ordinance are subject to the same procedural safeguard. ${ }^{69}$ Similarly, conditional use permits may require approval of the county planning commission and issuance of a variance will require a showing of individual hardship. ${ }^{70}$ Such administrative decisions are subject to judicial review. Although the individual property owner affected by condemnation proceedings is given a judicial hearing at which time he may attack the public purpose and good faith of the acquisition, ${ }^{71}$ the public is not invited to participate. Apparently, no formal proceedings are required for the sale or release of the rights acquired by the government.

If procedural and planming safeguards are required as a matter of constitutional law in order to validate a scheme of regulation by condemnation, both powers will stand on equal footing. If they are not so required their existence will depend on the nature of the enabling legislation. If the transactions involved in a scheme of regulation by condemnation are left solely to the discretion of the goverming authorities, such a program would seem to be an open invitation to arbitrary and discriminatory conduct, graft, collusion, and class and racial discrimination. To this sort of criticism Whyte answers that we must have faith in democracy, ${ }^{72}$ but faith alone may not suffice where the "irresponsibihty" due to sectional planming is compounded by the temptations of real estate speculation and the forces of prejudice.

In addition, an open space program effectuated by the police power may also be subject to disruption by exception whenever a landowner can show that his land

65 Hawthorne v. Peebles, 166 Cal. App. 2d 758, 333 P.2d 442 (1959) ; Sacramento Municipal Util. Dist. v. Pacific Gas \& Elec. Co., 72 Cal. App. 2d 638, 165 P.2d 741 (1946).

66 Eves v. Zoning Bd. of Adjustnient, $401 \mathrm{~Pa} .211,164$ A.2d 7 (1960).

o7 Whyte 9.

68 Gilgert v. Stockton Port Dist., 7 Cal. 2d 384, 60 P.2d 847 (1936).

69 Johnston v. Claremont, 49 Cal. 2d 826, 323 P.2d 71 (1958); CAL. Gov'T Code $\S 65804$.

70 Essick v. City of Los Angeles, 34 Cal.2d 614, 213 P.2d 492 (1950); Tustin Heights Ass'n v. Board of Supervisors, 170 Cal. App. 2d 619, 339 P.2d 914 (1959).

71 People v. Chevalier, 52 Cal. 2 d 299, 340 P.2d 598 (1959) (may attack the question of public use but not the question of public necessity); People v. Lagiss, 160 Cal. App. 2d 28, 324 P.2d 926 (1958).

72 WHYTE 45. 
cannot yield a reasonable return as restricted. This criticism is no doubt valid and, as previously discussed, is largely created by the absence of any authority to condemn the land as an alternative to rezoning or granting a variance. ${ }^{73}$ It is important to point out, however, that where there is no reasonable use of the land as restricted, no particular advantage is to be obtained fron condemning an interest less than the fee.

\section{Flexibility}

Although an effective open space program must be able to resist market and sectional political pressure, it must also comprehend growth and the means must be provided to allow adjustment to changing conditions. Regulation by condemnation has not heretofore been successful in this regard, ${ }^{74}$ and the legal problems created by an attempt to introduce flexibility into the approach should be indicative of the practical problems which may result. Subsequent condemnation of the fee and resale thereof may be required to allow development. If the restriction is to be treated as a property right, enforcement will probably require a civil action. Effective supervision nuay, therefore, require continuous litigation. The entire problem of long range administration and enforcement has been iguored by those concerned solely with the acquisition of open space as an end in itself.

On the other hand, "the police power is not a circumscribed prerogative, but is elastic and ... capable of expansion to meet existing conditions of modern life and thereby keep pace with the social, econonnc, moral, and intellectual evolution of the human race. In brief, "there is nothing known to the law that keeps more in step with human progress than does the exercise of this power. "75

\section{Existing Authorization and Enabling Legislation Required}

The utility of a program must also depend on the availability of the means and the necessity for additional enabling legislation. An open space program to be effectuated by the acquisition of developmental rights must include the power of eminent domain to be effective. Cities have no inherent power of eminent domain and it can only be supplied by enabling legislation. ${ }^{70}$ Counties, too, must depend upon enabling legislation to exercise the power. ${ }^{77}$ Under existing law, cities and connties are authorized to acquire the fee or any lesser interest in open areas to hmit their future use or to preserve their open character. Acquisition may be by purchase, gift, grant, bequest, devise, lease or otherwise. ${ }^{78}$ The legislative history apparently indicates that the term "otherwise" was not meant to include the power of eminent domain. ${ }^{79}$ The above authorization is limited to the territorial jurisdiction of the city or county.$^{80}$ Open space is defined as "an area characterized by (1) great natural scenic beauty or (2) whose existing openness, natural condition or present state of use, if retained, would enhance the present or potential value of abutting or surrounding urban development, or would maintain

73 Krasnowiecki \& Paul, supra note 4, at 191.

74 BASSET, ZoNing 26-27 (1936).

75 Miller v. Board of Pub. Works, 195 Cal. 477, 485, 234 Pac. 381, 383 (1925).

76 City and County of San Francisco v. Ross, 44 Cal.2d 52, 279 P.2d 529 (1955).

77 See, e.g., People v. Superior Court, 10 Cal. 2d 288, 73 P.2d 1221 (1937).

78 CAL. GOV'T CODE $\$ 6950$.

79 See 12 Stan. L. Rev. 638, 645 (1960).

80 CAL. GOV'T CODE $\$ 6952$. 
or enhance the conservation of natural or scenic resources." 81 The "open space" legislation is apparently designed to preserve aesthetic values or land values attributable to aesthetic considerations. Assuming these purposes are by themselves valid, the legislation may nevertheless be objectionable on the ground that, since the exercise of the power authorized is entirely discretionary, no "control" is provided to assure that the acquisition is in the public interest.

In contrast to the power of eminent domain, cities and counties derive their power to regulate under the police power directly from the Califorma constitution. ${ }^{82}$ Counties and non-chartered cities, however, are limited to regulations that are not in conflict with general laws. California Government Code sections 65800 through 65857 provide the general scheme and authorize the legislative body of any county or city to regulate the use of "buildings, strnctures and land as between agriculture, industry, business, residence and other purposes."

District and area plannimg commissions may be created with the consent of the governing authorities of a city or county but they function in an advisory capacity only.$^{83}$ Although a regional agency may be authorized to exercise the power of eminent domain, serious constitutional problems may arise if the legislation attempts to authorize any agency other than a city or county to enact zoming ordinances. ${ }^{84}$ Unless the purposes of an open space program may be characterized as state or metropolitan rather than municipal, similar problems of local home rule may arise should the legislature attempt to create a regional agency with the power to enact ordinances superseding city or county ordinances ${ }^{85}$ without their consent. ${ }^{86}$

To the extent that the police power is immediately available, the developmental rights approach would seem to be at a disadvantage. Present legislation authorizing acquisition of such rights is limited to consensual arrangements and aesthetic purposes. Any attempt to accomplish the broader purposes of an open space program will require additional legislation.

It is clear that enabling legislation is necessary to effectively accomplish the objectives of an open space program by either means: first, to provide plannimg control and financial and political responsibility on regional bases; and second, to authorize eminent domain proceedings as an alternative to regulation under the police power, either to supplement the latter power or to replace it as a primary means to achieve the desired end.

81 CAI. Gov't CODE $\$ 6954$. $\S 11$.

82 Hurst v. City of Burlingame, 207 Cal. 134, 277 Pac. 308 (1929); CaL. Const. art. XI,

83 CAL. Gov'T CODE $\$ \S 65000-800$.

84 Gilgert v. Stockton Port Dist., 7 Cal. 2d 384, 60 P.2d 847 (1936), holding that an act authorizing the creation of a port district was unconstitutional insofar as it attempted to confer authority to zone property within its boundaries. The grounds of the decision were apparently twofold: first that article $\mathrm{XI}, \S 11$ of the California constitution was an exclusive grant of authority to cities and counties to enact pohice regulations; and second, that the legisiature could not delegate its power to determine what acts constitute a crime and punish accordingly. Both grounds of the decision are questionable, however, and may not be followed by a modern court.

85 Even if a regional district can be authorized to enact zoning ordinances, conflicting county or city ordinances will prevail over district ordinances, unless they are for state or possibly metropolitan purposes. In re Werner, $129 \mathrm{Cal}$. 567, $62 \mathrm{Pac} .97$ (1900); Town of Atherton v. Superior Court, 159 Cal. App. 2d 417, 324 P.2d 328 (1958).

86 Brooks, The Metropolis, Home Rule, and the Special District, 11 Hastrnas L.J. 110, 246 (1959). 


\section{CONCLUSIOIN}

The constantly recurring legal objection to the developmental rights approach to regulation is that, absent certain safeguards, it is peculiarly susceptible to abuse. Without the discipline of comprehensive planning which includes economic and utilitarian as well as aesthetic considerations, without inherent physical limitations, without the protection of laws general in application, and without adequate procedural safeguards, the exercise of the powers required becomes entirely discretionary, subjective, and perhaps unconstitutional. Enabling legislation designed to control urban and suburban development curing these defects will no doubt be upheld. Authorization for the more restricted aesthetic purposes may be upleeld if it includes adequate safeguards.

Large open space areas suitable both for agrarian use and development may be successfully regulated under the police power. Individual areas not suitable for development and having a reasonable open space use may also be "conserved" without compensation. Planning under the police power, however, is subject to disruption by exception whenever a showing can be made that the general plan is unreasonable as applied. Compensable regulation is required in those exceptional and himited areas where a restricted open space area is so surrounded by development that the restriction would amount to "spot zoming"; where the restriction is without sufficient economic or utilitarian justification, i.e., aesthetic and probably recreational zoning; and where no reasonable use of the land can be made as restricted. Theoretically there should be hittle or no cost savings in condemning an interest less than the fee in this last case.

In sum then, regulation under the police power is valid and inherently more useful for the accomplishment of the broader purposes of an open space program: to prevent untimely or undesirable development; to prevent developnent in plysically unsuitable or uneconomic locations; to preserve and protect agriculture as a necessary and desirable part of the community; to prevent congestion and create cohesive and well-balanced communities. These are economic and practical objectives having aesthetic value as well.

On the other hand, condemnation of the fee or any lesser interest is peculiarly adaptable to the narrower, specialized, and more permanent aesthetic and recreational values of a comprehensive open space program.

What is needed is a marriage of the two powers in enabling legislation authorizing the exercise of either power on a regional basis pursuant to a comprehensive plan with adequate administrative and procedural safeguards to prevent irresponsible administration. Conceivably, this could be accomplished by authorizing a landowner to initiate proceedings in the nature of an inverse condemnation action for compensation for an unreasonable restriction; by authorizing the government to cross complain for condemnation when the reasonableness of a regulation is attacked; and by requiring a reviewable determination that compensation is constitutionally required when acquisition is contemplated. Short of this, the ad hoc acquisition of developmental rights in existing open space areas may create more problems than it solves.

If the developmental rights approacl is limited to the acquisition of relatively permanent interests in areas where a reviewable determination is made that compensation is required, and where condemnation of less than the fee represents a significant cost savings, many of the problems peculiar to the use of that technique as an instrument of regulation would be eliminated. Condemnation as an excep- 
tion to the rule rather than as the rule reduces the necessity for flexibility and implies a greater degree of certainty, permanency, and responsibility. The areas subject to condemnation would be relatively few, thus reducing the cost of the program. Comparable development values would be readily ascertainable. Evaluation for compensation purposes would be less speculative. Zoning regulations would be less susceptible to change. Property could be equitably assessed at its restricted value.

Limited to areas where noncompensable regulations are either inequitable or unjustifiable, the ultimate constitutional, planning, and political question, which should be kept separate from the imdependently justifiable objectives of an open space program, is squarely presented: whether, in each case, the aesthetic value of the land to the public wlien compared with its developmental value and personal value to the owner is sufficient to jusitfy the acquistion of the developmental rights but insufficient to justify regulation without compensaion or acquisition of the fee. More particularly, "should large estate owners or private golf clubs be favored in any manner because they offer to the passing public a restful view, a natural view? Should the public have a right of access to any property secured in one manner or another for the purpose of benefiting the public?" 87 In short, is the view alone worth it?

Burton Danziger*

87 Davidoff, Book Review, 26 J. Adrertcan Instrutute of Planners 337, 339 (1960).

* Member, Class of 1962. 